Erika Seres Huszárik, PhDr., PhD. candidate, assistant professor, Assistant professor of marketing and economics, Department of Economics, Faculty of Economics, J. Selye University (Komárno, Slovakia);

László Józsa,

Prof. Dr., CSc., professor, Professor of marketing, Department of Economics, Faculty of Economics, J. Selye University (Komárno, Slovakia);

Andrej Hevesi,

Mgr., PhD. candidate, assistant, Department of Foreign Languages, Faculty of Economics, J. Selye University (Komárno, Slovakia)

\title{
CLIENT GROUPS IN THE EARLY STAGE OF THE LIFECYCLE OF BUSINESS RELATIONSHIPS ON THE ADVERTISING MARKET
}

The development of $B 2 B$ relations is researched by many scholars. Besides dealing with the stages of the lifecycle the aim of this study is to introduce client groups in Slovakia with the help of the factors that influence relationships on the advertising market the most. After joining an international research group, besides dealing with the above mentioned factors, in our primary research we set out to research Slovak client groups on the Slovak advertising market and to describe them on the basis of their behaviour. We suppose that clients can be segmented on the advertising market just like on every other market. Thus, our hypothesis is the following: There are distinctive client groups in the early stage of the lifecycle model. In order to ensure comparability, in our survey we used a questionnaire that was already successfully tested in Hong Kong. Our respondents were Slovakian advertising agencies and their clients. Our research results showed that the researched Slovak businesses can be put into two groups in the early stage of the business relations: the risk-averse segment and the risk taking segment. Thus, we consider the carrying out of segmentation also on the advertising market important, which can result in offering customised services to clients.

Keywords: customer relations, lifecycle, advertising market, client groups, segmentation, Slovakia.

DOI: $10.21272 / \mathrm{mmi} .2017 .3-02$

Formulation of the problem generally. The cooperation between two businesses is influenced by a number of factors. There is cooperation between business entities on a vast number of levels. The nature of the relationship, of course, largely influences which factors have an impact on the quality of that particular cooperation. The agency-client lifecycle theory approaches and deals with the relationship between these two parties as a process. It stresses that cooperation between the parties and the development of their relationship is influenced by a number of factors. Besides the objective factors there are a number of subjective ones that can cause significant changes in the cooperation, such as the change of the client's attitude to the relationship. It is very important for advertisers to build good relationships with advertising agencies in order to make sure that their promotional campaigns work smoothly. An unsuccessful relationship or the termination of the relationship costs time, money and energy: a new campaign has to be made, the finding of a new agency and building trust with it takes time. Experience shows that it takes approximately two years in the advertising business to build a new and stable relationship. It is also important to mention that building a relationship is a dynamic process. A business builds and ends a countless number of relationships during its existence [19].

Analysis of recent researches and publications. Before dealing with the literature on relationship marketing let us have a look at the essence and specific features of B2B marketing. A relation in general is an interaction between two entities. In business relationships usually there is a business on one side and a group of individuals (buyers) on the other side. A group of economists within B2B marketing do not recognize the relevance of relationship marketing until personal interaction between the company and its 
customers is established. Their argument is justified by the fact that the exchange of information exclusively through ICT does not result in real contacts between the parties. This group of researchers is of the opinion that a real relationship can only be established through customer-relations staff who need to be in regular contact with the company's clients. On the basis of this it can be concluded that the building of a relationship between to businesses is just as difficult and complicated as the maintenance of a buyer-seller relationship [5].

If we study the Slovak and international literature on relationship marketing (hereinafter RM), we will find its several definitions.

Francová and Oreský [6, p. 44] define RM as a system with an aim to "create, maintain and develop mutual relationships with stakeholders to create value for the sake of customer satisfaction." RM primarily deals with the maintenance of relationships with clients, competitors, the public and state institutions. RM, which can also be interpreted as a modern marketing tool, helps companies to remain competitive.

Michalková [15, p. 102] interprets RM as "the link between the organisation and the customers, employees, suppliers and other partners with the aim of exploiting long-term mutual benefits for the parties." It emphasizes the special customized approach, which makes clients feel important. This feeling makes clients want to establish and develop a relationship with the business.

Machková [13, p. 14] sees the essence of RM as follows: "the basic goal of the company must be the building of long-term, positive customer relationships. Getting to know the special needs of customers is the way to achieve this goal." The author says that consumers are not only the end users of a company's products or services, but approaches this question from a wider sense, and states that clients are all entities that influence the organization's operation.

In addition to the researchers' views outlined above, there are further important scholars who have contributed to the development of relationship marketing:

- Kotler [12] identified the four major steps of RM. As a first step the most important clients must be found, experienced executives must be appointed, and the processes must be elaborated for the managers.

- Bolton [2] researched customer loyalty. He found that customer loyalty is the factor that influences relationships the most, since it makes customers come back again to the company as clients.

- According to Gounaris [7], the business relationship is a result of a psychological process where the parties cooperate to achieve a mutual aim.

- Cao and Gruca [3] argue that cooperation is a two-party agreement in order to reach the set business goals.

- Payne and Frow [17] define relationships as the means of access to investment resources.

- According to Jha [11], business relationships are born for the reason that one party hopes that their help provided to the other one in the present will be returned by the other party in the future.

- According to Da-wei [4], achieving customer satisfaction that can be achieved by electronic means is the most important goal of RM.

- Green's [8] research suggests that the establishing and development of a relationship is a result of previous customer experience.

- According to Omar [16], business relationships are the result of interdependency and the author believes that currently there is no better solution on the market than cooperation between the parties [9].

The organization of customer relationships is one of the most complex challenges for business leaders. The ability and willingness to cooperate is one of the fundamental and essential prerequisites for establishing successful business relationships, while maintaining these relationships is also an extremely important task. The process of establishing, organizing and maintaining a relationship is a complex activity that can dynamically change over time, as new problems that must be solved arise all 
the time.

In the following, we will focus on the most determining factors of relationships between advertising agencies and their clients. The main benefits of using the services of an advertising agency include time saving, simplification of administrative activities and the existence of quality control activities. Additionally, the customer receives information and advice regarding a specific area, and can get professionalism, cheaper media space and additional information. By this means expenses can be decreased [1]. Agencies make maximum effort to secure customer satisfaction.

Advertising agencies are businesses that provide specific services under certain conditions set out in a professional manner. It is common in this market that the agency has an exclusive contract with its client, which, in addition to the usual assignments, includes other agreements and arrangements that are typical of the area.

In examining the relationship between agencies and clients, we face four basic issues. The first one is the efficiency of the above discussed relation. Effective co-operation is the basis for a long-term and stable partnership, in which the parties have to follow the following principles:

1) Confidence building - a fundamental building block for business relationships. The business partners agree that the client will not communicate to the competitors how the agreement was reached, and will not order the service from another agency. At the same time, the client expects from the agency to be a committed partner.

2) The deadline for the payment of services - financial issues in business, just like in private life, are a sensitive area of cooperation; therefore, the client must pay attention to settle all debts in time and to a full extent.

3) Discounts provided for the client - there are many forms of this. The agency can offer discounts as a sign of gratitude to the client, in case of long-term contracts, regular timely payments etc.

4) Taking responsibility - the client must comply with predetermined rules and avoid aggressive behaviour in order to maintain a long-term relationship. Aggressive behaviour is a very common reason for ending a business relationship.

5) Quality of services - quality services is significant importance in all business areas. This is also especially true in the field of marketing services. Quality service includes the high quality of the service provided, but also the price and compliance with the agreed terms.

6) Written agreement - based on the opinion of experts in the field, all related activities should better be put down on paper. This is one of the keys to long-term and stable business relationships. For example, putting down the payment terms and the conditions for the fulfilment of the order on paper are of paramount importance.

7) Communication between the parties - communication between the partners is essential in order to avoid problems. Regular meetings can generate new ideas, can provide solutions to new challenges and contribute a lot to efficient problem solving. These activities help both parties coordinate their activities and in the schedule [18].

The second thing to be examined is the question of what causes the termination of an agency-client relationship. According to Halinen [10], there can be six reasons for ending an existing business relationship:

1) Low level of service - the decline in the quality of the services provided by the agency is one of the most common reasons why the client terminates the relationship. In most cases, this happens when the agency already has a reputation in the market and must simultaneously come up the expectations and fulfil the needs of more and more customers.

2) Degree of employee turnover - if there is high staff turnover in the agency, it is relatively common that the client is unable to become used to the personality of the new contact person and will leave the agency. 
3) Poor coordination - improper management and coordination of projects can lead to the termination of the entire project.

4) Loss of trust - one of the most serious mistakes of agencies is to let confidence lost. If it happens, it is almost certain that the client will look for a new partner.

5) Significant changes in the project - if the parties cannot adapt to the new circumstances, it will mean the end of the business relationship.

6) Personal conflicts - the human factor is one of the most critical factors in business life. It can influence the success of a partnership in a positive and in a negative sense as well [10].

Another important question in the relationship is how the agency gets new clients, and perhaps more importantly, how it can retain its existing customers and improve the quality of the relationship. Improving the quality of relationships is mainly influenced by key factors, such as mutual understanding, trust, flexibility and respect.

Aims of the article. Several aims were elaborated prior to the conducting of the research itself. Our primary and most important goal is to identify the customers of advertising agencies in the initial stage of the business relationship, and that similarly to the well-known consumer groups (innovators, early adopters, majority, and lagers) used in research on the product life cycle. Being familiar with customer groups is of utmost importance in order to be able to address them with customised marketing solutions. This increases their trust, which can result in the development of long-term business relationships between the parties. In order to reach the above aim we elaborated the following research questions:

Who are the clients? Can they be put into different groups?

Following the elaboration of the research questions the hypothesis was set up:

$\mathrm{H}$ : There are distinctive client groups in the early stage of the lifecycle model.

We chose to apply a deductive research method, since our aim was the testing of the hypothesis and the analysis of relations. The most suitable way to implement our research project was to conduct a single cross-sectional survey, since we collected data once from a single sample [14]. In our survey we used a questionnaire that was already successfully tested in Hong Kong. It was provided for us by one of the research leaders, Professor Fam. To evaluate the early stage of the cooperation respondents had to respond to 33 statements. Here a semantic differential scale was used. The questionnaires were filled in online and anonymously, and only one questionnaire could be sent back from one e-mail account. Since we surveyed the advertising market of two countries, the questionnaires were sent out in Hungarian or in Slovak, depending on the location of the given business's seat. The respondents were approached and the questionnaires were filled out in 2014 and 2015. First, a database had to be elaborated about the advertising agencies operating on the markets of the two countries. During the creation of our database of agencies we used websites, which present the available advertising agencies as well as the websites of advertising-agency associations. There were 637 agencies in the final database. The online questionnaire was sent out to them, and we also asked them to forward us contacts for their client so that we could make the questionnaire available for them as well. On the basis of the facts above it can be stated that our research method was the snowball method belonging to non-random sampling techniques. As a result of the above described method our questionnaire was made available for 2,648 businesses. 23 requests were returned immediately due to wrong e-mail addresses. Following the filtering of improperly or only partially filled out questionnaires 339 properly filled out questionnaires were left to work with. Thus, the size of the research sample was 339 , which means a $13.1 \%$ willingness to respond. This rate is a normal one since respondents tend to be reluctant to participate in similar surveys, or they are afraid that their data would get into the hands of their competitors. A third of the respondents were agencies, and two-thirds were clients; so there were 114 and 225 of them, respectively. 153 responding businesses were from Hungary and 186 were from Slovakia.

After the received data had been checked, they were processed with the help of the SPSS software 
package. In order to prove or disprove the hypothesis several questions had to be evaluated jointly.

Basic material. With the hypothesis we would like to find out whether the surveyed businesses can be put into different groups on the basis of the variables included in the questionnaire and which are typical for the early stages of cooperation. Our hypothesis states that

$\mathrm{H}$ : There are distinctive client groups in the early stage of the lifecycle model.

In order to test the hypothesis we conducted a cluster analysis in SPSS. First, we determined the ideal number of clusters by applying Ward's method, which necessitated the creation of two groups in the early stage of the relationship.

144 businesses belong to the first cluster, which makes up $81 \%$ of the sample. These businesses think that the market-research competencies of the agency are very important. Business growth, the existence of international contacts and the administration of projects are similarly crucial for them. These are all factors that show how precise the agency is. The least important criteria for clients in choosing an agency are the agency's size, its product portfolio, the awards the agency has won, the stability of its workforce and the help they provide in the elaboration of long-term strategies. As it can be seen from the table and the above described facts the agency's precise work and its experience is important for this group; however, they consider the stability of the relationship and its maintenance less important in the early stage of the relationship. In this light our first cluster was named the cluster of risk-averse businesses needing precision and experience.

With its 33 businesses, the second, smaller, cluster makes up $19 \%$ of the sample. The thing they consider important when choosing an agency is its willingness to share information with them, namely to warn the client if it is about to make a wrong business decision and to inform the client about the latest global market trends. The facts whether the agency has international contacts or to what extent their top managers take part in decision making is not important for them at all. Since international contacts and relations, business expansion, the administration of projects and the way invoices are handled are not important for them, this cluster got the name of information-hungry risk takers not needing precision.

On the basis of the survey our hypothesis $\mathrm{H}$ that:

There are distinctive client groups in the early stage of the lifecycle model.

Can be considered proved, since on the basis of the results of the cluster analysis carried out in SPSS we could identify two distinct client groups.

In the following we will characterise the clusters on the basis of variables not included in the cluster analysis (Table 1).

Table 1 - Comparison of clusters created in the early stage of the relationship (own data)

\begin{tabular}{|c|c|c|c|}
\hline & & $\begin{array}{l}\text { risk-averse businesses needing } \\
\text { precision and experience }\end{array}$ & $\begin{array}{l}\text { information-hungry risk } \\
\text { takers not needing precision }\end{array}$ \\
\hline \multirow[t]{4}{*}{$\begin{array}{l}\text { strength of } \\
\text { relationship }\end{array}$} & distance & feeling closer than risk takers & keeping distance \\
\hline & future cooperation & more possible than risk takers & less possible \\
\hline & recommending to others & recommend more than risk takers & recommend less \\
\hline & promotional budget & $\begin{array}{l}48 \% \text { with considerable capital tie- } \\
\text { up above } 75 \%\end{array}$ & $\begin{array}{l}45 \% \text { with minimum capital tie- } \\
\text { up }\end{array}$ \\
\hline number of employees & & $67 \%$ are small businesses & $55 \%$ are micro-businesses \\
\hline gross revenues & & $\begin{array}{l}41 \% \text { with revenues between } \\
301,000 \text { and } 500,000 \text { EUR }\end{array}$ & $\begin{array}{l}36 \% \text { with revenues below } \\
100,000 \text { EUR }\end{array}$ \\
\hline \multirow[t]{3}{*}{$\begin{array}{l}\text { distribution of } \\
\text { campaigns }\end{array}$} & national market & $65 \%$ & $83 \%$ \\
\hline & foreign market & $11 \%$ & $4 \%$ \\
\hline & multinational market & $28 \%$ & $13 \%$ \\
\hline \multicolumn{2}{|c|}{$\begin{array}{l}\text { membership in the association of advertising } \\
\text { agencies }\end{array}$} & $62 \%$ are members & $55 \%$ are not members \\
\hline
\end{tabular}


With the help of the other questions we aimed to find out how close clients feel to their agencies. The respondents had to mark on a scale of 1 to 7 to evaluate how close their cooperation is, where 7 meant very close cooperation and 1 meant very week. Since the question measured on a metric scale, but clusters are not of metric scale, we used the ANOVA method in the remaining part of the analysis. The risk-averse cluster have a more positive view on the strength of their relationship with the agencies in all three question fields than the other cluster; however, it can also be stated that there were mostly negative answers to all questions in both clusters. Thus, both the risk taking and the risk-averse cluster fell rather distant from their advertising agency with an average of 3.46 and 3.00 , respectively. They both are less sure that they will still be cooperating with the same agency in 3-5 years (average $=3.67$ and 3.18). Similarly, the businesses in both groups are less sure (average $=4.02$ and 3.09 ) that they would recommend their agency to other clients.

The significance level of the individual statements was tested with an F-test. At a $5 \%$ significance level it can be stated that there are differences between the two clusters regarding their opinion about their closeness to their agency and their willingness to recommend their agency to others. On the basis of this, the risk-averse cluster has a slightly more positive view on the strength of the relationship than the risk-taking one.

When measuring the strength of the relationship we also used the question from the questionnaire, which asked about how many percent of the client's promotional budget is managed by the given agency. Naturally, the higher percent a given agency handles from the promotional budget, the stronger the relationship is, since this way the client becomes dependent on the agency regarding the success of its campaigns. The clients could respond to this by answering an open question. During the analysis, however, we thought it would make more sense to categorise the responses. The following categories were set up: below $26 \%$, between $26 \%$ and $50 \%$, between $51 \%$ and $75 \%$ and more than $75 \%$. The responses in the two clusters were analysed through a cross-table analysis. The results are shown in the figure below (Figure 1):

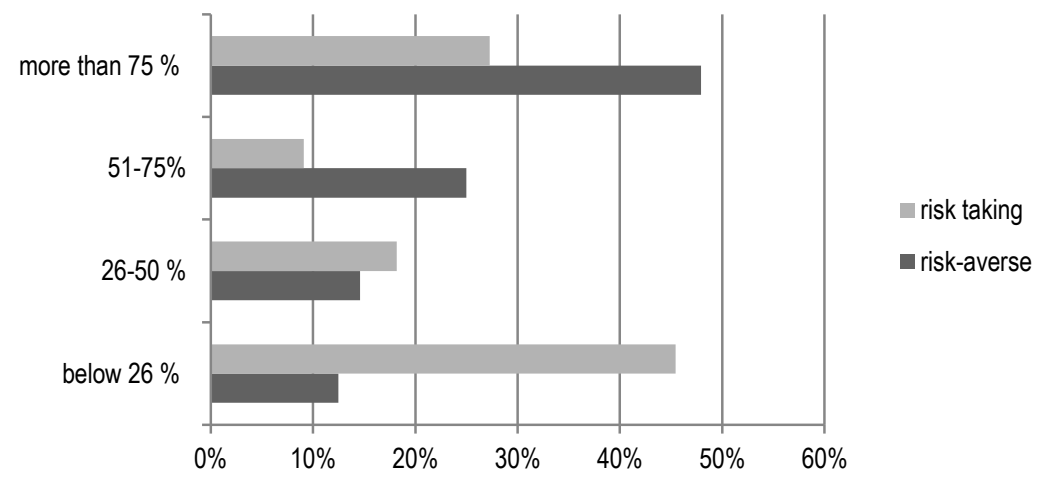

Figure 1 - The relation between clusters and their capital tied-up by advertising agencies (own data)

Following the analysis it can be claimed that the risk taking cluster provides a smaller percent of their budget to be managed by their agency and they depend less from the agency than the businesses in the risk-averse cluster, where as much as $48 \%$ of the businesses are willing to let even more than $75 \%$ of their promotional budget be managed by an agency. The link between the two variables was also tested with an F-test: the value was 12.465 at a significance level of 0.001 . Thus, it can be concluded that there is a certain level of correlation between the two factors. The indicator showing the strength of the 
correlation took up the value of $\eta 2=0,066$, which shows a week correlation.

The respondents were also put in the following categories regarding their size: micro-businesses, small businesses, medium-sized businesses and corporations. There is no correlation between the two analysed factors (clustering as an independent variable and the number of employees as a dependent variable). Despite this, let us analyse the number of employees of businesses in the two clusters. A significant proportion of businesses $(67 \%)$ in the risk-averse cluster are small businesses with 10-49 employees. Contrary to this, more than half $(55 \%)$ of the businesses in the risk taking cluster are microbusinesses. Thus, the assumption those micro-businesses are more flexible in responding to market changes and challenges might prove to be true; therefore, they are willing to take bigger risks.

When answering the question about their revenues in 2015 businesses could choose from seven options (less than 100,000 EUR, 101,000-150,000 EUR, 151,000-300,000 EUR, 301,000-500,000 EUR, 501,000-750,000 EUR, 751,000-1m EUR, more than 1m EUR).

Table 2 - Analysis of variance of the clusters in the initial stage of the lifecycle based on their gross revenues in 2015 (own data)

\begin{tabular}{|l|c|c|c|}
\hline \multicolumn{4}{|c|}{ ANOVA Table } \\
\hline & $\mathrm{F}$ & Sig. & Eta Squared \\
\hline Businesses revenues in 2015 & 29,369 & 0,000 & 0,148 \\
\hline
\end{tabular}

The analysis of variance showed correlation $(F=29,369$; sig. $=0,000)$ between the clustering of businesses and their revenues in 2015. The indicator showing the strength of the correlation took up the value of $\eta 2=0,148$, which shows a week correlation (Table 2 ).

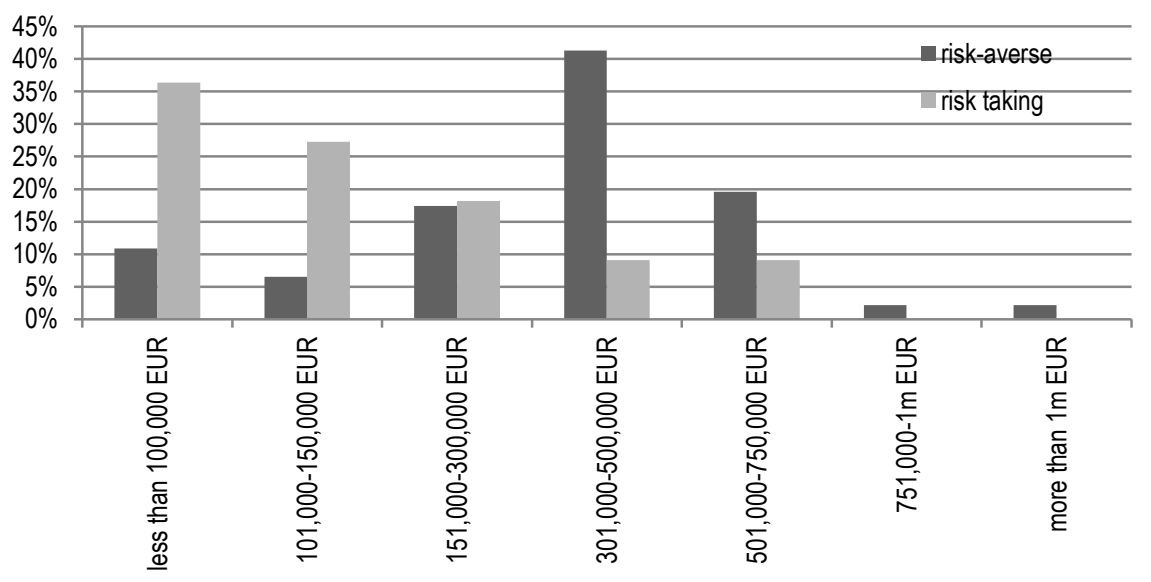

Figure 2 - Businesses revenues in 2015 (own data)

The distribution of the responses by the clusters' members indicates interesting results. As it can be seen in the figure above (Figure 2), a considerable proportion of the risk-averse group (41\%) had revenues between 301,000 and 500,000 EUR in 2015. The distribution of the responses copies the line of a bell-shaped curve. Contrary to this, the majority of the risk taking businesses ( $81 \%$ of them) had gross revenues lower than 300,000 EUR in 2015 . Thus, it seems that there is no positive correlation between the decision of taking or avoiding risk and the amount of annual revenues. Therefore, it is not 
true that the higher a company's revenues are, the more business risk it is willing to take. Therefore, with regards to the present study it can be claimed that businesses with higher revenues tend to play it safe when choosing a new advertising agency, and do not like taking risks in the early stage of cooperation.

With the survey we also wanted to find out whether the clients mostly target national markets, foreign markets or multinational markets with the campaigns. The results of the analysis of variance are shown in the table below (Table 3).

\section{Table 3 - Analysis of variance of clusters in the early stages of the lifecycle on the basis of the distribution of advertising campaigns (own data)}

\begin{tabular}{|l|c|c|c|}
\hline \multirow{2}{*}{ Distribution of advertising campaigns } & \multicolumn{2}{|c|}{ ANOVA } & \\
\cline { 2 - 4 } & F-test & Sig. & $\eta^{2}$ \\
\hline home market & 21.527 & 0.000 & 0.110 \\
\hline foreign market & 4.714 & 0.032 & 0.036 \\
\hline multinational market & 25.526 & 0.000 & 0.127 \\
\hline
\end{tabular}

The table shows that not depending on whether the campaigns are run at home, abroad or multinationally there is a significant but weak correlation between the two clusters and the place of the campaigns. While on average $83 \%$ of the campaigns of risk takers are run at home, the same proportion is $65 \%$ in the risk-averse group. The businesses in both clusters rather focus on home markets: the proportion of marketing activities abroad in the risk-averse and the risk taking cluster is $11 \%$ and only $4 \%$, respectively. The proportion of multinational campaigns among the risk-averse cluster is $28 \%$. The same figure amounts to $13 \%$ in the risk taking one (Figure 3).

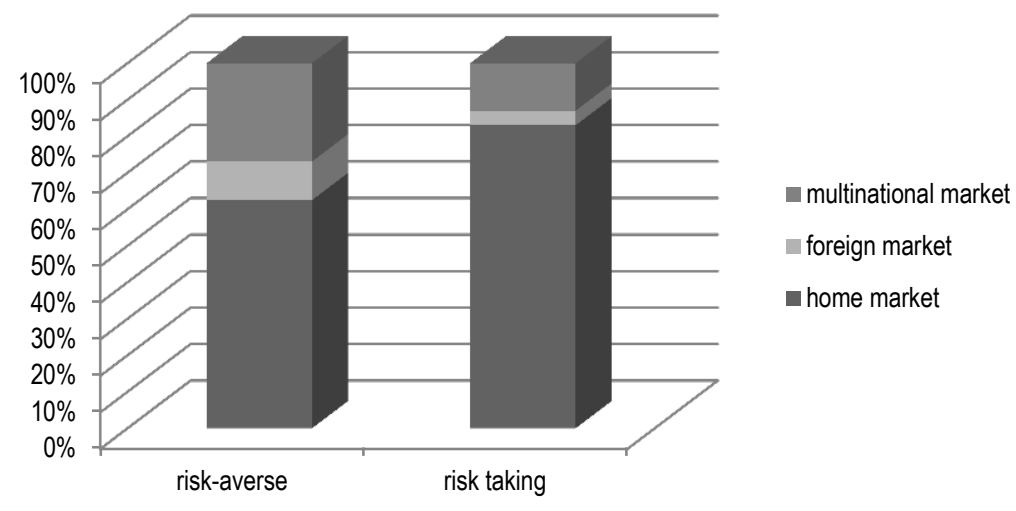

Figure 3 - Distribution of marketing activities in the clusters on different types of markets (own data)

To sum up, it can be concluded that not depending on which cluster they belong to the researched businesses tend to focus their advertising activities on home markets. However, it can also be seen that the risk-averse cluster have a wider scope of activities with higher proportions of advertising activities abroad or on multiple markets.

No significant correlation was shown between membership in the given country's association of advertising agencies and being in a certain cluster of this research $\left(x_{2}=0,194\right)$. The distribution of responses shows that approximately a third of the advertising agencies of the risk-averse cluster are members of the association and belong to the Top 10 agencies; another third of them are members of 
the association and the remaining third are not members of the association of advertising agencies. The majority $(55 \%)$ of the risk taking cluster cooperate with agencies that are not members of the association of advertising agencies.

Conclusions and directions of further researches. We identified two clusters in the early stage of the business relation. We considered clustering important for the reason that in a market as specialized as the advertising one there is a need to segment customers. It is necessary in order to create a targeted marketing plan, since the addressing of each of our segment should be done in a different way. The risk-averse businesses needing precision and experience feel closer to their agency even at the beginning of the relationship than the risk taking cluster. They also expect longer cooperation with their agency than risk takers and they recommend their agency to others more. Agencies tie-up more than $75 \%$ of the advertising budget of the risk-averse cluster in spite of the fact that it causes that they depend largely on the agency. The majority of the cluster has been on the market for 5 to 10 years and their annual revenues range between 301,000 and 500,000 EUR. The majority of their campaigns target home markets, but they also focus on multinational ones. Based on the characteristics of the cluster, it can be stated that there is a need to build trust with them as early as possible, since they are more loyal to their chosen agency than the members of our second cluster. It is important for the staff of the advertising agency not to disappoint these cluster members; thus the staff of agencies should be trained and developed. The feeling of trust can be further enhanced through formal and informal meetings.

Contrary to the above described cluster, the information-hungry risk takers not needing precision feel farther from their agency; they do not think they will work together with their agency in the future as well, and they are reluctant to recommend the agency to others. Their risk taking nature is also shown in the fact that their agencies tie up only low proportions of their advertising budget. The majority of the cluster is micro-businesses and has been on the market for 11 to 15 years and their annual revenues are lower than 100,000 EUR. A considerable proportion of their advertising campaigns are run exclusively at home markets, and they tend to work with advertising agencies that are not members of the national association of advertising agencies.

Thus, our second cluster is made up of clients that have a lower annual turnover, but have been on the market for a longer period and their business is firmly settled. This might be the reason for the fact that they are willing to take risks. To gain the trust of this segment there is a need to make them feel that all information regarding the market and the joint projects is always made available to them. It may be useful for the agency to create a joint information database with the customers in this segment.

1. Batra, R., \& Myers, J.G. (2009). Advertising managment. Sri Lanka: Dorling Kindersley.

2. Bolton, R.N. (2000). Handbook of Relationship Marketing. London: SAGE.

3. Cao, Y., \& Gruca, T.S. (2005). Reducing advertising selection through customer relationship Management. Journal of Marketing, 69(7), 219-229.

4. Da-Wei. (2007). Study on the factors of customers' loyalty in e-business world. Proceedings of the International Conference on Wireless Communications, Networking and Mobile Computing, Shanghai, China.

5. Francová, Z. (2008). Vzt'ahový marketing v obchode - implementácia, nové smery využívania v kontexte teórie Josepha Schumpetera [Relationship Marketing in Business - Implementation, New Uses in the Context of Joseph Schumpeter Theory]. Zborník príspevkov k vedeckému projektu - Proceedings of the Scientific Project, 1(7), 21-39 [in Slovak].

6. Francová, Z., \& Oreský, M. (2010). Vzt'ahový marketing: od teoretických východísk po uplatnenie v praxi [Relationship marketing: from theoretical sources to practice]. Bratislava: Vydavatel'stvo EKONÓM [in Slovak].

7. Gounaris, P.S. (2005). Trust and commitment influences on customer retention: insights from business-to-business services. Journal of Business research, 21(4), 126-140.

8. Green, M. (2009). Social CRM as a business strategy. Journal of Database Marketing Customer Strategy Management, 18(1), 50-64

9. Gupta, A., \& Sahu, G.P. (2013). Factors influencing adoption of relationship marketing practices for overall growth of firm: an ISM-based model validition. Electronic Customer Relationship Management, 7(1), 21-44.

10. Halinen, A. (2007). Relationship marketing in Professional services. New York: Routledge.

11. Jha, L. (2008). Customer Relationship Management. New Delhi: Global India. 
12. Kotler, P. (2001). Marketing Management. Praha: Grada.

13. Machková, H. (2015). Mezinárodni marketing: strategické trendy a př́klady z praxe [International Marketing: Strategic Trends and Practice Examples]. 4. vyd. Praha: Grada Publishing [in Czech].

14. Malhotra, N.K. (2009). Marketingkutatás [Marketing Research]. Budapest: Akadémiai Kiadó [in Hungarian].

15. Michalková, L. (2008). Formy priameho marketingu aplikované na budovanie vzt'ahov so zákazníkmi. Vzt'ahový marketing ako nástroj konkurencieschopnosti podniku: medzinárodné vedecké kolokvium [Forms of direct marketing applied to building relationships with customers. Relationship Marketing as an Instrument for Competitiveness of the Enterprise: International Scientific Colloquium]. Bratislava: EKONÓM [in Slovak].

16. Omar, M.W. (2010). Brand loyalty and relationship marketing. Canadian Social Science, 7(1), 25-32.

17. Payne, A., \& Frow, P. (2005). A strategic framework for customer relationship management. Journal of Marketing, 69(4), 167-176.

18. Singh, V. (2010). Assignment of Client Agency Relationship. Chadinagh: Panjab University Press.

19. Waller, D.S. (2004). Developing an account management lifecycle for advertising agency-client relationships. Marketing Intelligence \& Planning, 22(1), 95-112.

E.C. Гусзарік, PhDr., PhD. candidate, асистент, кафедра економіки, економічний фракультет, Університет ім. Я. Шейе (м. Комарно, Словаччина);

Л. Йозса, Prof. Dr., CSc., професор, кафедра економіки, економічний факультет, Університет ім. Я. Шейе (м. Комарно, Словаччина);

A. Гевесі, Mgr., PhD. candidate, асистент, кафедра іноземних мов, економічний фракультет, Університет ім. Я. Шейе (м. Комарно, Словаччина)

Клієнтські групи на ранньому етапі життя бізнес-відносин на рекламному ринку

Багато дослідників вивчають розвиток відносин В2В. Метою даного дослідження, крім розгляду етапів життєвого ииклу, є впровадження клієнтських груп в Словаччині за допомогою факторів, які впливають на відносини на рекламному ринку. Після вступу до міжнародної дослідницької групи, крім вирішення вищезазначених чинників, в нашому основному дослідженні ми вирішили дослідити словацькі клієнтські групи на словацькому ринку реклами і описати їх на основі їхньої поведінки. Ми вважаємо, що клієнти можуть бути сегментовані на рекламному ринку, як на будь-якому іншому ринку. Таким чином, наша гіпотеза така: на ранній стадії життєвого циклу існують відмінні групи клієнтів. Щоб забезпечити порівнянність, в нашому опитуванні ми використовували анкету, яка вже була успішно протестована в Гонконзі. Нашими респондентами були словацькими рекламними агентствами та їхными клієнтами. Результати наших досліджень показали, що досліджувані словацькі підприємства можуть бути представлені на двох етапах на ранніх етапах ділових відносин: сегмент, уникаючих ризику, і сегмент, схильних до ризику. Таким чином, ми вважаємо, що проведення сегментації також важливо на рекламному ринку, що може призвести до надання клієнтам індивідуальних послуг.

Ключові слова: відносини з клієнтами, життєвий цикл, рекламний ринок, групи клієнтів, сегментація, Словаччина

э.C. Гусзарик, PhDr., PhD. candidate, асистент, кафедра экономики, экономический факультет, Университет им. Я. Шейе (г. Комарно, Словакия);

Л. Йозса, Prof. Dr., CSc., профессор, кафедра экономики, экономический факультет, Университет им. Я. Шейе (г. Комарно, Словакия);

A. Гевеси, Mgr., PhD. candidate, ассистент, кафедра иностранных языков, экономический факультет, Университет им. Я. Шейе (г. Комарно, Словакия)

\section{Клиентские группы на раннем этапе жизни бизнес-отношений на рекламном рынке}

Многие исследователи изучают развитие отношений В2В. Целью данного исследования, помимо рассмотрения этапов жизненного цикла, является внедрение клиентских групп в Словакии с помощью факторов, которые влияют на отношения на рекламном рынке. После вступления в международную исследовательскую группу, помимо решения вышеупомянутых факторов, в нашем основном исследовании мы решили исследовать словацкие клиентские группь на словацком рынке рекламы и описать их на основе их поведения. Мы полагаем, что клиенты могут быть сегментированы на рекламном рынке, как на любом другом рынке. Таким образом, наша гипотеза такова: на ранней стадии жизненного иикла существуют отличительные группы клиентов. Чтобы обеспечить сопоставимость, $\theta$ нашем опросе мы использовали анкету, которая уже была успешно протестирована в Гонконге. Наши респонденть были словацкими рекламными агентствами и их клиентами. Результаты наших исследований показали, что исследуемые словацкие предприятия могут быть представлены на двух этапах на ранних этапах деловых отношений: сегмент, избегающих риска, и сегмент, склонных к риску. Таким образом, мы считаем, что проведение сегментации также важно на рекламном рынке, что может привести к предоставлению клиентам индивидуальных услуг.

Ключевые слова: отношения с клиентами, жизненный цикл, рекламный рынок, группы клиентов, сегментация, Словакия.

Отримано 13.03.2017 p. 